\title{
Developing digital multimedia of human anatomy and physiology material based on STEM education
}

\author{
Nuril Hidayati a,1,*, Farizha Irmawati b,2 \\ a Department of Biology Education, Faculty of Exact and Sport Science Education, IKIP Budi Utomo, Jl. Citandui 46, Malang, \\ East Java, 65122, Indonesia \\ Department of Physical Health Education and Recreation, Faculty of Exact and Sport Science Education, IKIP Budi Utomo, \\ Jl. Citandui 46, Malang, East Java, 65122, Indonesia \\ hidayatinuril20@gmail.com *; 2 farizha99@gmail.com \\ * Corresponding author
}

\begin{tabular}{|c|c|}
\hline ARTICLE INFO & ABSTRACT \\
\hline $\begin{array}{l}\text { Article history } \\
\text { Received June 04, 2019 } \\
\text { Revised October 30, 2019 } \\
\text { Accepted November 19, } 2019 \\
\text { Published November 30, } 2019 \\
\\
\text { Keywords } \\
\text { Critical thinking } \\
\text { Multimedia } \\
\text { STEM education }\end{array}$ & $\begin{array}{l}\text { The development of multimedia based on science, technology, engineering, and } \\
\text { mathematics (STEM) to empower students critical thinking skills has not been optimally } \\
\text { carried out. The purpose of this research was to develop multimedia of human anatomy } \\
\text { and physiology material based on STEM which improve students' critical thinking skills. } \\
\text { This research and development (R\&D) used } 4 D \text { Thiagarajan development model which } \\
\text { consisted of define, design, develop, and disseminate. The instruments used were } \\
\text { interview guidelines, observation sheets, questionnaires, and test. The data obtained } \\
\text { consisted of quantitative and qualitative data. The quantitative data was obtained from the } \\
\text { test results and the assessments of respondents using a Likert scale, while the qualitative } \\
\text { data in the form of experts recommendations. The results showed that the media developed } \\
\text { were classified as valid with the scores were } 96.89 \% \text { (media aspects), } 97.53 \% \\
\text { (usefulness), and } 85.22 \% \text { (readability). Furthermore, the prerequisite test results showed } \\
\text { that the data are spread normally (p>0.05) and homogeneously (p>0.05) so that the } \\
\text { ANACOVA test is continued. The ANACOVA test results showed that students' critical } \\
\text { thinking skills taught with multimedia were significantly difference (sig }<0.05) \text {.This study } \\
\text { recommends the use of multimedia in learning human anatomy and physiology. }\end{array}$ \\
\hline
\end{tabular}

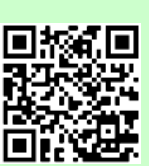

Copyright $\odot$ 2019, Hidayati et al This is an open access article under the CC-BY-SA license

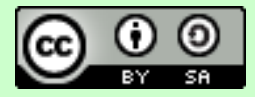

How to cite: Hidayati, N. \& Irmawati, F. (2019). Developing digital multimedia of human anatomy and physiology material based on STEM education. JPBI (Jurnal Pendidikan Biologi Indonesia), 5(3), 497-510. doi: https://doi.org/10.22219/jpbi.v5l3.8584

\section{INTRODUCTION}

Nowadays, the 21 st-Century learning issue is a interesting topic that has been researched and developed (Bellanca et al., 2010; Chu, Reynolds, Tavares, Notari, \& Lee, 2016; Dwyer, Hogan, \& Stewart, 2014). Topics such as critical thinking skills (Miharja et al., 2019; Scott, 2015), problem solving (Binkley et al., 2012; Nithyanantham, Paulmony, \& Hasan, 2019), and collaborative learning (Tsuneyoshi, 2016; Vieira, Melo, Avraamidou, \& Lobato, 2017), examined from various perspectives are major issues that are believed to be key

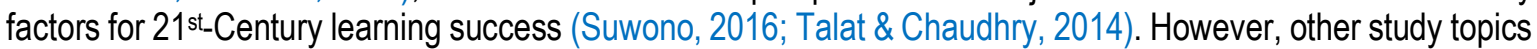
that integrate the process of problem identification, hypothesis design, determination solutions, to application in 
a multidisciplinary manner indicated to be able to encourage students' thinking skills more comprehensively (Guleker, 2015; Huff, 2014; Thompson, 2011). The study of the integration of science, technology, engineering, and mathematics (STEM) has been carried out at almost all levels of education ranging from basic education (Baharin, Kamarudin, \& Manaf, 2018), secondary education (Torlakson, 2014; Yusuf, Amin, \& Nugrahaningsih, 2017), to higher education (Groshans et al., 2019). These studies focus on various aspects such as relevant learning strategies (Iriti, Bickel, Schunn, \& Stein, 2016), specifics subject to be taught (Baram-Tsabari \& Lewenstein, 2013), and the developing learning media (Akopian, Melkonyan, Golgani, Yuen, \& Saygin, 2013).

On the other hand, the use of media in the learning process is believed to be an effort to provide a meaningful learning experience for students (Aflalo \& Gabay, 2013; Isaacs, 2012; Ismail, Harun, Zakaria, \& Salleh, 2017). Technological developments, including in the education fields and learning, have an impact on how efforts need to be made to develop media based on science and refer to the latest developments (Leow \& Neo, 2014; Mehdipour \& Zerehkafi, 2013; West, 2015). One of technology-based development is the integration of text, image, video, and sound in one integrated media (Ary, Jacobs, Sorensen, \& Razavieh, 2010; Crozat, Hu, \& Trigano, 1999). Implementing of multimedia is believed to be able to facilitate the occurrence of meaningful learning processes and experiences for students (Maria, Rusilowati, \& Hardyanto, 2019; Umachandran et al., 2019). Meaningful learning is indicated to be able to facilitate students in optimizing thinking skills (Iversen, Pedersen, Krogh, \& Jensen, 2015; Korres \& Tsami, 2013) which in turn will determine how he understands the concepts being studied (Kiliç \& Sağlam, 2014), especially if the concepts are very complex such as human anatomy and physiology (Himschoot, 2012; Oakes, Hegedus, Ollerenshaw, Drury, \& Ritchie, 2019).

Concepts learned in the course of human anatomy include the study of the complex anatomy and physiology of the human body (Mader \& Windelspecht, 2010). These complex characteristics require the use of multimedia that visualizes the material and empowers students' critical thinking skills (Dick, Carey, \& Carey, 2015; Leow \& Neo, 2014; Nusir, Alsmadi, Al-Kabi, \& Sharadgah, 2013). The observations results that have been made in the anatomy of human physiology courses show that learning is not optimal in developing thinking skills and tends to give students space to memorize concepts. In addition, the media used in the learning process are partial media that have not been integrated with developing learning models and technologies.

This research aims to develop multimedia anatomy of human physiology based on STEM education. The STEM learning approach will be included in the multimedia design that will be developed. The eight stages of STEM education will be integrated into the student activity sheet section in addition to the material developed. The developed multimedia will go through several stages until finally it is feasible to be used as teaching material. Multimedia anatomy of human physiology based on STEM education that has been developed will have a real contribution in enriching the variety of media that can be used by teachers in the classroom, especially in Indonesia, so as to improve the quality of learning. This research can also be a reference for researchers in the STEM field and efforts to develop meaningful learning experiences for students.

\section{METHOD}

This development research uses a four step model developed by (Thiagarajan, Semmel, \& Semmel, 1974) covering define, design, and disseminate. The define phase begins with a front-end analysis to identify learning problems. This stage involved 38 students who had taken anatomy in human physiology. Identifications made at this stage include the characteristics of students as media users. In addition, an analysis of the breadth and depth of the material was carried out to determine learning outcomes and indicators. At this stage also carried out identification of the weaknesses of teaching materials used. The results of this stage of analysis are used as a basis for developing product prototypes at the design stage.

The prototype design consists of preparing a reference test as an instrument to measure changes in student behavior, selection of media content, and determination of multimedia formats using Adobe Flash software in the form of swf.exe. The developed multimedia prototype is composed of several sections including overwiew, material content, worksheets, identification of personal abilities, e-books, and evaluation. Multimedia prototypes that have been produced are then developed with validation of the truth of the concept, its feasibility and usefulness. Validation is done by involving material experts, media experts, and practitioners. Readability test was also carried out on a product prototype involving 38 students.

Product dissemination is done by testing the effectiveness of multimedia on students' critical thinking skills. The product effectiveness testing was conducted on students of Biology Education Study Program IKIP Budi Utomo Malang. The test was carried out using a quasi-experimental design. A total of 76 students involved as 
research subjects were divided into two classes. One class learns to use STEM-based multimedia products while another class with general multimedia (not STEM-based).

Data collection techniques were using interviews, observation, and questionnaires. The instrument used were interview transcript, observation transcript, needs analysis questionnaire, expert and practitioner validation questionnaire, and trial questionnaire which has been adapted from (Hidayati, 2016). The data were analyze qualitatively to gather information from validation and trial activities. The research data was calculated by the formula 1. Furthermore, the calculation results will be categorized according to the validity criteria of the results of validation and trials in Table 1. Data obtained from disseminating activities to determine the effectiveness of multimedia in improving critical thinking skills will be adapted to the higher-order thinking categories (Table 2) adopted from (Ichsan et al., 2019).

$P=\frac{\sum X}{\sum X 1} \times 100 \%$

Table 1. Criteria of validation and trial result

\begin{tabular}{ccc}
\hline Range (\%) & Validation criteria & Description \\
\hline$\geq 81$ & Very valid & No Revision \\
$61-80$ & Valid & No Revision \\
$41-60$ & Quite valid & Revision \\
$21-40$ & Invalid & Revision \\
$0-20$ & Very invalid & Revision \\
\hline
\end{tabular}

Table 2. Categories of thinking ability of students

\begin{tabular}{cc}
\hline Category & Interval score \\
\hline Very high & $x>81,28$ \\
High & $70,64<x \leq 81,28$ \\
Moderate & $49,36<x \leq 70,64$ \\
Low & $38,72<x \leq 49,36$ \\
Very low & $x \leq 38,72$ \\
\hline
\end{tabular}

\section{RESULTS AND DISCUSSION}

The results of front-end analysis showed that the anatomical material of human physiology taught using multimedia only reached $38.10 \%$, while $92.86 \%$ of students considered multimedia to greatly assist them in understanding a concept. On the other hand, learning based on e-learning has been done by $77.38 \%$ of students. These results indicate that the use of e-learning is not yet fully supported by good media utilization. Furthermore, the results of interviews with lecturers show that students tend not to communicate and collaborate during the learning process. This limitation causes students to not be able to build the concepts learned (Pang, Lau, Seah, Cheong, \& Low, 2018; Rufii, 2015).

The results of front-end analysis are related to the results of the analysis of student characteristics. The results of the analysis show that learning responsibilities are low so they tend to be passive. This situation makes learning not conducive because students tend not to follow the ongoing process (Jack, 2013). This is also compounded by the limited references students have. The available references in the form of electronic books (e-books) do not necessarily increase student enthusiasm for learning, on the contrary students have difficulty understanding the concepts in them (Song \& Bonk, 2016). Students actually look enthusiastic when learning to use PowerPoint and torso media. However, students also feel guilty about using these two media.

Task and concept analysis shows that the material identified many misconceptions in students includes the nervous system, sensory system, and muscular system. The three materials were developed using eight stages of STEM-based learning, including defining problems, connecting with real life, planning investigations, analyzing and interpreting data, drawing simple conclusions, designing alternative solutions, discussing the solutions obtained, and evaluating and communicating results (Torlakson, 2014). The results of objective analysis lead to the development of student skills. Teaching human anatomy and physiology must use learning models that provide opportunities to empower critical thinking skills. It can be seen from the critical thinking indicators (Table 3 ) in course learning outcome (CLO) and subject learning outcome (SLO) that need to be developed are interpretation, analysis, evaluation, inference, explanation, and independent regulation. Based on the information found above it can be seen that the learning process that is not supported by the use of 
media and appropriate learning models will be able to make learning outcomes that are not good so that this becomes a serious problem.

The integration of questions that stimulates critical thinking skills is embedded in the product prototype design stage. Reference-criteria tests are carried out to analyze aspects of the skills that will be developed in the product. The questions are arranged on each material contained in the three product sections including worksheets, compiling independent questions, and evaluating. The test settings referenced by the criteria have been validated by experts so that the form and type of questions are in accordance with the indicators of critical thinking skills and the material developed. in addition, the characteristics of the developed multimedia product are the integration of the STEM learning model in the student activity sheet section, mastery of concepts and the development of students' critical thinking skills. An overview of STEM-based multimedia products as in Figure 1.

Table 3. CLO and SLO which will be developed in multimedia of human physiology anatomy based on STEM

\section{CLO of human anatomy physiology}

Distinguish the structure of the constituents of muscle tissue which make up muscular system, cells, and connection among skeleton and muscles in movement.

\section{SLO of human anatomy physiology}

1. Distinguish structure and function of skeletal muscle cells, smooth muscle cells, and myocardium cells.

2. Describe the physiological mechanism of skeletal muscle cells contraction through the theory of filament displace, smooth muscle cells with single and plural unit concept, and myocardium cells following all or none principle.

3. Classify the constituent muscles of human body and its action mechanism.

4. Identify disorder and abnormalities toward muscular system

Describe nerve cells, mechanism of nerve action, central nervous system (brain) and the edges (spinal cord) and the connection of nerves activities with the other systems

1. Describe nerve cells and their physiological parts and functions

2. Describes impulse propagation mechanism (physiological nerves, polarization, depolarization, and repolarization)

3. Categorize central nerves system and peripheral nerves system

4. Compare mechanism of reflex motion and normal motion

5. Explain disorder and abnormality in nerves system

Sensory organ, mechanism of sensory activity $1 . \quad$ Describe the role of receptors $\begin{array}{lll}\text { mechanism connected to nerves system. } & 2 . & \text { Identify receptors on the skin }\end{array}$

3. Describe vision mechanism of eyes

4. Describe hearing mechanism of ears

5. Analyze smell mechanism in nasal

6. Explain tasting mechanism on tongue

7. Explain action mechanism of sense of balance

8. Describe abnormality and diseases in sensory system

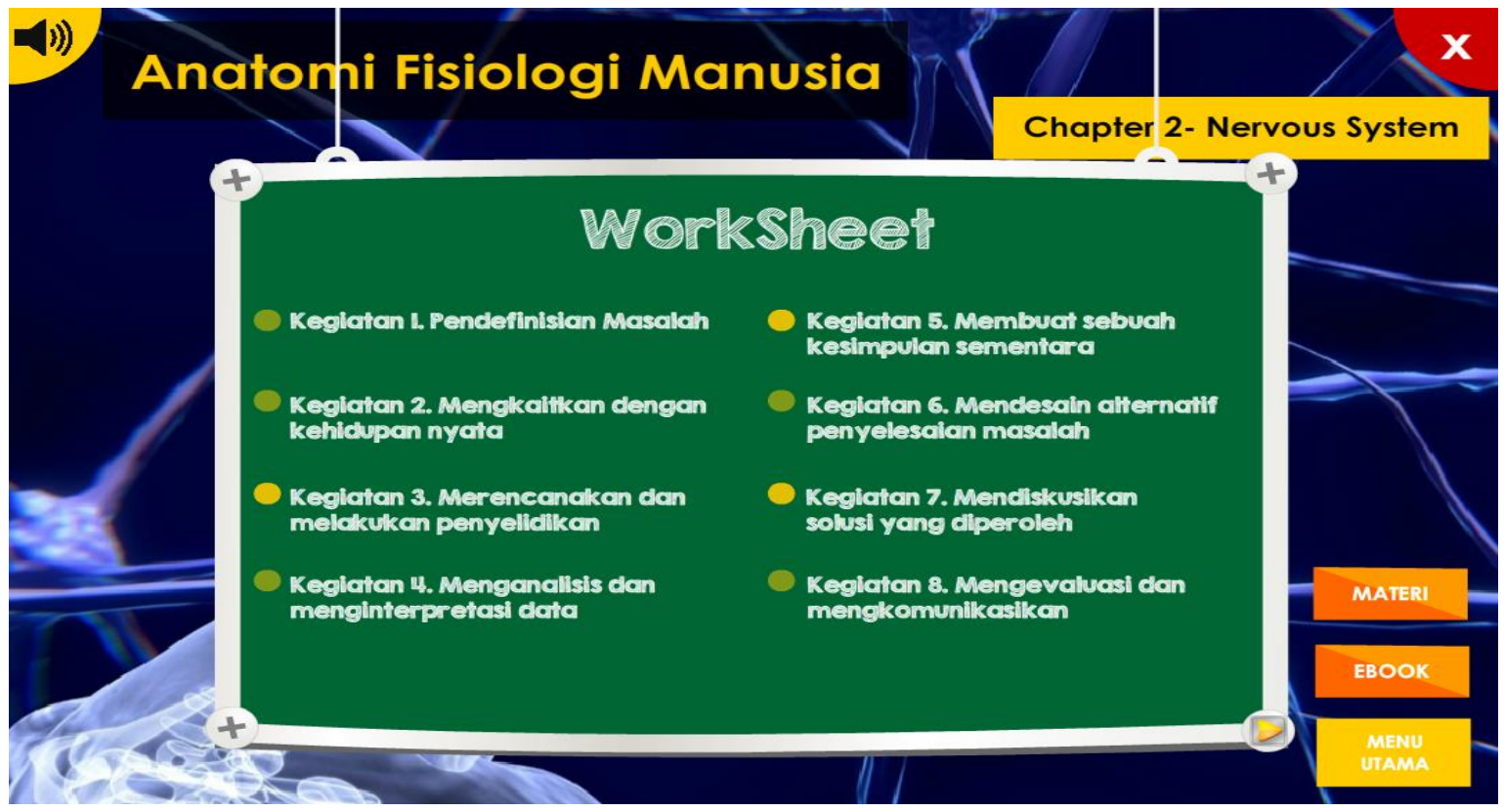

Figure 1. Display of STEM-based student worksheet on multimedia human anatomy and physiology 
Development of multimedia products at the design stage based on practicality, effectiveness, efficiency and independence. Access to the use of multimedia using the Indonesian language. It aims to make it easier for students to understand the concepts being studied. According to some researchers, the practicality and efficiency of use must be considered in the development of media so as not to complicate user access (Muchlis \& Putra, 2017; Nurrohmah, Putra, \& Farida, 2018). Likewise with the effectiveness and independence of media use. The effectiveness of the media is measured based on its performance affecting certain variables to be achieved using these media, also be seen from how the media is accessed by users (Irwan, Maridi, \& Dwiastuti, 2019; Nusir et al., 2013). The format used in the development of this media allows students to access multimedia anytime and anywhere, both individually and in groups.

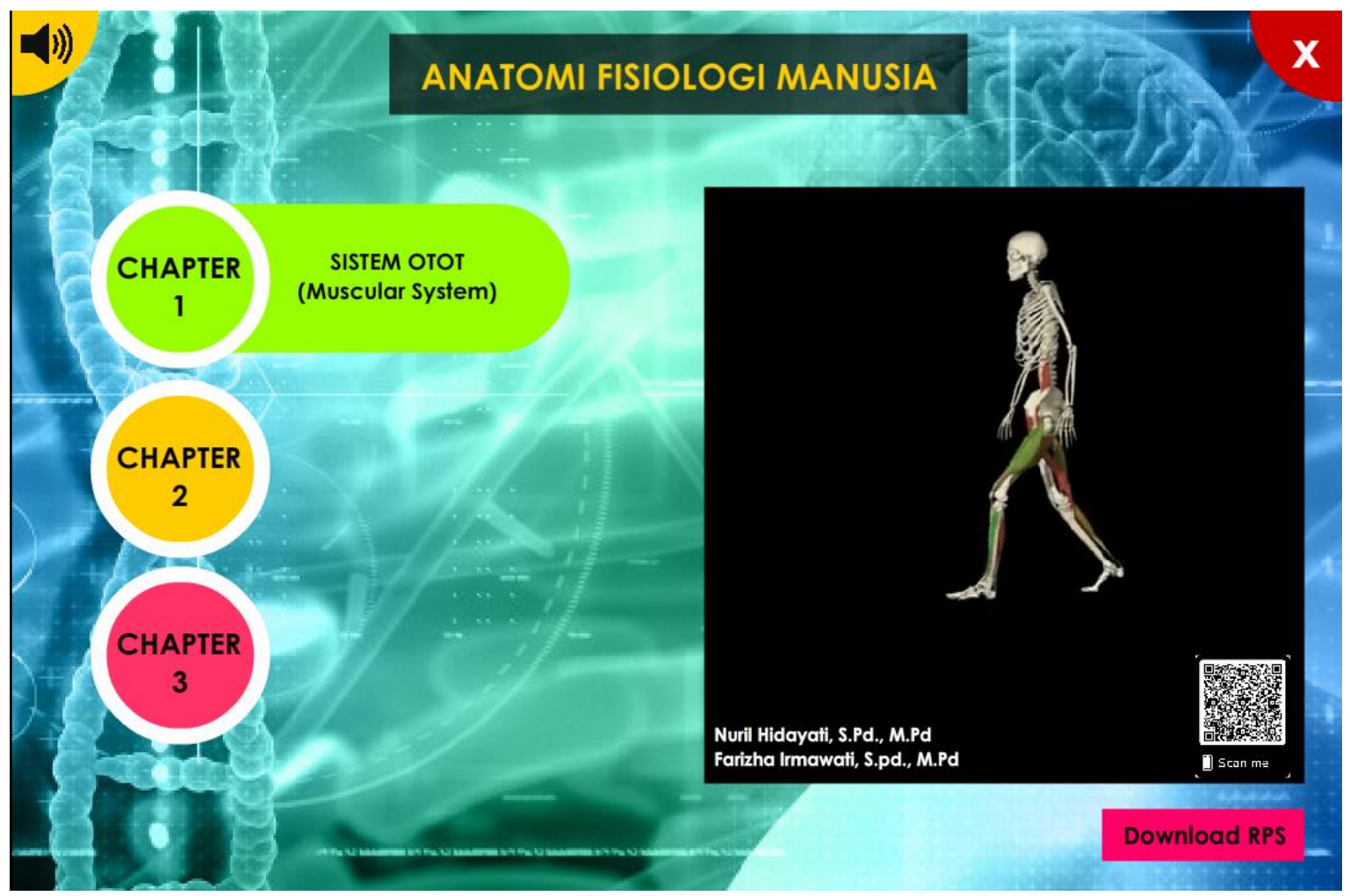

Figure 2. The display of STEM-based multimedia start menu

Multimedia developed consists of two parts to facilitate use. At the beginning (Figure 2) there is identity, course outline, the three chapters of the material to be studied, and instructions for use. The second part is a more specific part in multimedia which is composed of overview, materials, e-books, worksheets, self-abilities, and the evaluations (Figure 3). The overview contains a description of CLO and SLO (Table 3), concept maps, and it is equipped with navigation buttons leading to the material sections. The material is composed of concept descriptions related to the anatomy and physiology of the body system that is being studied and is equipped with relevant pictures and videos (Çimer, 2012; Himschoot, 2012). Students can also access the main references by downloading the e-book available in this section. Student learning activities in multimedia are controlled using STEM-based student worksheets (Korres \& Tsami, 2013; Valerio, 2012). The self-ability rubric available in this multimedia is used to practice students' critical thinking skills. Evaluation is the final part in this multimedia. Students can access this rubric after learned and accesed all available features. The evaluation rubric is arranged so that during use students cannot access other features until they complete the evaluation and the evaluation score appears.

The results of experts validation in the development stage show that multimedia products are valid. The validation of media expert (Table 4) shows that the assessment elements which included visualization, design, typography, illustration, language readability, and completeness of the presentation were classified as very valid (score $\geq 81 \%$ ). This shows that the multimedia developed is very interesting. Some researchers argue that the attractiveness (Crozat et al., 1999) of media such as image and sound selection (Raaijmakers et al., 2018), display resolution (Wang, Wu, \& Wang, 2009), layouting (Bahar, Aydin, \& Karakirik, 2009; Fitriani, Adisyahputra, 
\& Komala, 2018), and display balance (Siagian, Mursid, \& Wau, 2014) need to be considered in order to focus the user's learning attention.

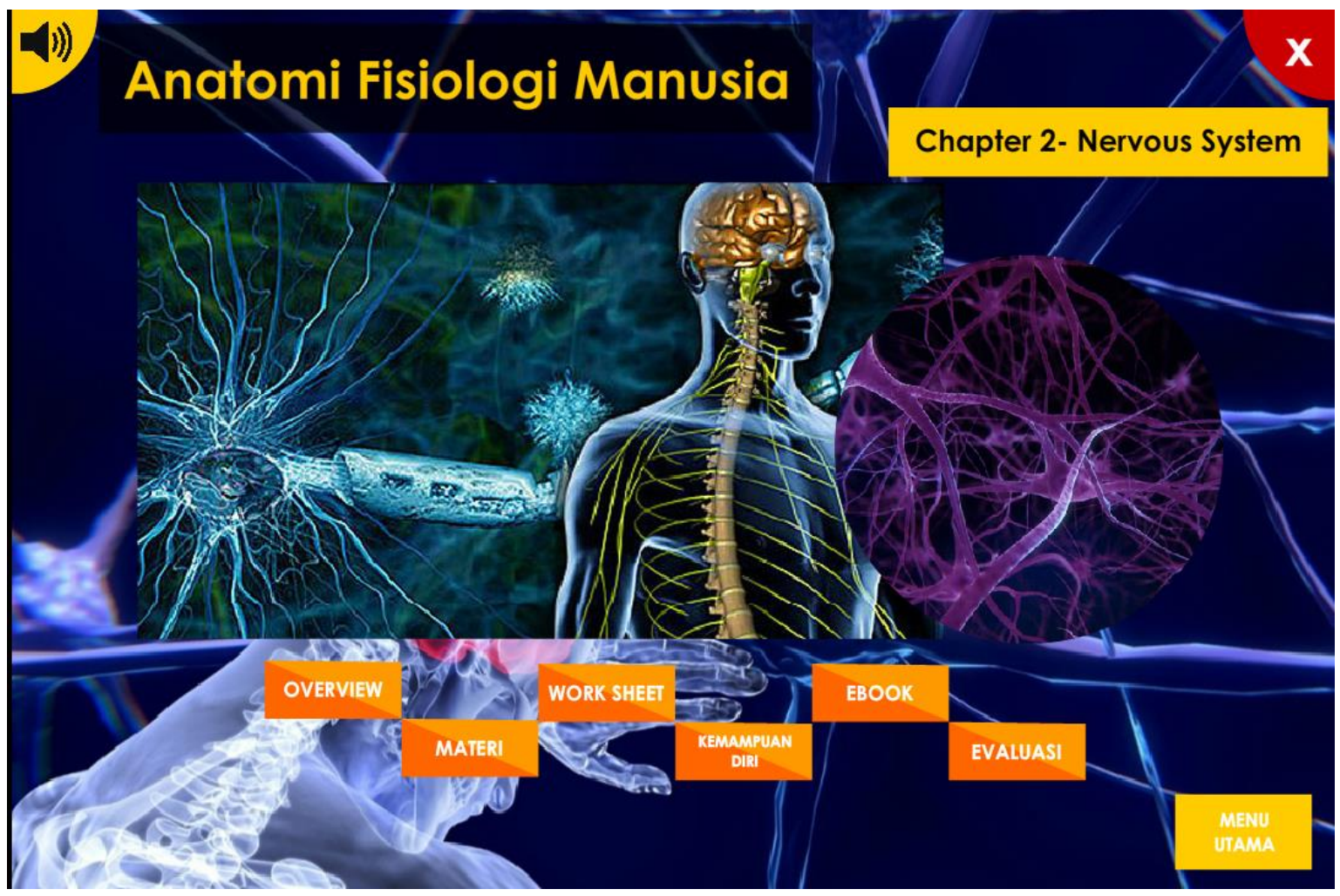

Figure 3. The display of nervous system chapter

Table 4. The results of media experts validation

\begin{tabular}{clcc}
\hline No & \multicolumn{1}{c}{ Question } & Score (\%) & Criteria \\
\hline 1 & Multimedia visualization (multimedia compatibility with standard and material size) & 87.50 & Very valid \\
2 & Multimedia design (appearance, design, composition and size of menu layout, and colour) & 100 & Very valid \\
3 & Multimedia typography (identity and colour used) & 100 & Very valid \\
4 & Multimedia illustration (describing content menu) & 100 & Very valid \\
5 & Writing design (writing in paragraphs, spaces, subtitles used, illustrations and captions, videos & 92.86 & Very valid \\
& visualization, and navigation buttons menu) & 100 & Very valid \\
6 & Typography content (type, background, and colour) & 91.67 & Very valid \\
7 & Image illustration (meaning of images, images clarity, and images update) & 100 & Very valid \\
8 & Language feasibility (comprehension, language accuracy, standardization of terms, integrity of & 100 & Very valid \\
& meaning) & 96.89 & Very valid \\
\hline
\end{tabular}

Material expert validation as described in Table 5 shows that the five elements of assessment include the completeness of the material, the order of the material, and the concept described as very valid valid $(\geq 81 \%)$ while the element of conceptual accuracy and contextual application is classified as valid (75\%). Furthermore, the truth of the concepts in the three materials includes the muscular system, the nervous system, and the sensory system with a percentage score of $83.33,90$, and 96.88 , respectively. Concept accuracy is a fundamental factor in media development. Mistakes in describing concepts, according to some researchers, have a fatal impact on students' understanding of concepts. Bahri, Syamsuri, and Mahanal (2016) stated that the material presented in product development must have a high level of truth and there are no misunderstandings. Misunderstanding of the concept will have an impact on not achieving learning outcomes. Azizah, Kusumaningtyas, Anugraheni, and Sari (2018) stated that the material content of the product development must be accurate based on the concepts and theories applied. Thus, misunderstanding in multimedia developed can be avoided. 
Practitioner assessment results (Table 6) also show the use of multimedia products in the learning process is very valid $(97.53 \%)$. The menu variations contained in the product make it easy for students to access available information. The combination of materials is arranged neatly and schematically so that it helps students to master the correct concepts about the anatomy of human physiology. Types of student activities (worksheets) in multimedia are designed based on the steps of the STEM educational learning model and worksheets on multimedia are able to direct students to hone critical thinking skills. The form of questions or statements in multimedia can measure students' critical thinking skills. The statement is in accordance with (Ashaver \& Igyuve, 2013; Bahar et al., 2009) statement that the developed multimedia must have clear and easy learning content to be applied by users. Akopian et al (2013) added that product development must be developed in accordance with the expected learning objectives so that it is appropriate to be used to support the learning process.

Table 5. The results of material experts validation

\begin{tabular}{|c|c|c|c|}
\hline No & Question & Score $(\%)$ & Criteria \\
\hline 1 & Material completeness (compatibility with learning objectives and no material repetition) & 100 & Very valid \\
\hline 2 & Material accuracy (correct concept and contextual applications to material) & 75 & Valid \\
\hline 3 & Material presentation (material arrangement and sequence, and material relevance) & 83.33 & Very valid \\
\hline 4 & $\begin{array}{l}\text { Muscular system concept (the structure of muscle cells, and mechanism of contraction of } \\
\text { muscle cells, the mechanism of action of muscles, and abnormalities and diseases) }\end{array}$ & 90.63 & Very valid \\
\hline 5 & $\begin{array}{l}\text { Nerves system concept (structure and function of nerves cells, classification of nerve cells, } \\
\text { impulse propagation mechanism, nerves system classification and function, reflexes } \\
\text { mechanism, abnormalities and diseases) }\end{array}$ & 90 & Very valid \\
\hline \multirow[t]{2}{*}{6} & $\begin{array}{l}\text { Sensory system concept (type of receptor, sensory sense of touch, sense of smell, sense } \\
\text { of taste, sense of sight, sense of hearing and balance, and abnormalities and disease) }\end{array}$ & 96.88 & Very valid \\
\hline & Mean Score & 89.31 & Very valid \\
\hline
\end{tabular}

Table 6. The results of practitioners validation

\begin{tabular}{clcc}
\hline No & \multicolumn{1}{c}{ Question } & Score (\%) & Criteria \\
\hline 1 & Multimedia design (multimedia ease of use) & 100 & Very valid \\
2 & $\begin{array}{l}\text { Material completeness (suitability of the material with course outline, learning objectives, ease } \\
\text { of implementation, and general description) }\end{array}$ & 100 & Very valid \\
3 & $\begin{array}{l}\text { Material (constructing students' knowledge, material order accuracy, meaningfulness, and } \\
\text { systematics) }\end{array}$ & 93.75 & Very valid \\
4 & $\begin{array}{l}\text { Students' activities types (accuracy of activities types and material, stimulating motivation, } \\
\text { conformity with STEM learning model, sharpening critical thinking skill, ease of understanding } \\
\text { concepts) }\end{array}$ & 96.43 & Very valid \\
5 & $\begin{array}{l}\text { Questions/ statements forms (accuracy of question types with CLO and indicators of critical } \\
\text { thinking, questions feasibility and contextual relevance) }\end{array}$ & 95 & Very valid \\
6 & Conformity of students' development level (compatibility with level of thinking) & 100 & Very valid \\
\hline & $\quad$ Mean Score & 97.53 & Very valid \\
\hline
\end{tabular}

The development of content in a product allows changes in its components. These changes are based on expert advice and the results of feasibility tests are conducted. The revisions and improvements are presented in Table 7. Some of the changes made include the addition of material navigation buttons, worksheets, and selfability. This improvement makes it easy for students to access other menus when using multimedia. However, on the evaluation page, the material access button is removed to avoid the possibility of students accessing the material while working on the evaluation questions.

The results of small group trials (Table 8) show that multimedia developed is easy to use for students. However, there are some notes that need to be improved for product improvement such as aspects of increasing motivation and learning independence. The motivation and independence of learning aspect does not necessarily increase when using STEM-based multimedia. According to some experts, the growth of motivation depends on many aspects besides the availability of media (Rosli et al., 2015; Song \& Bonk, 2016). The availability of learning resources that are easy to understand (Cronje, 2016), communication with peers (Binkley et al., 2012), and the ability of teachers (Ertmer \& Newby, 2013) to develop learning strategies are aspects that need attention. Thus, the use of multimedia needs to be strengthened by the selection of strategies and other relevant learning resources in order to increase student motivation and learning independence.

The effectiveness of multimedia in improving students' critical thinking skills is presented in Table 9 and Table 10. The results of normality and homogenity tests (Table 9) with sig 0.05 indicate that the multimedia 
effectiveness test data are normally scattered (0.821) and homogeneous (0.610). ANACOVA results (Table 10) show that there are differences in critical thinking skills $(\mathrm{sig}<0.05)$ between students who learn by using STEMbased multimedia and those who are not. One indication of the difference is the ability of students to give an argument to a concept. Students who learn by using STEM-based multimedia, gradually, are able to build concepts based on the order and relevance of the material arranged in the media. Furthermore, the questions contained in the evaluation rubric accustom students in analyzing and solving problems related to the concept being studied. Both of these do not appear in student learning using powerpoint media, so students are not accustomed to using critical thinking skills in solving existing problems. Groshans et al (2019) and McCrum (2017) argues that STEM-based multimedia is able to overcome the limitations of the senses in understanding the concept so that the presence of multimedia is able to assist students in analyzing, criticizing, and reaching conclusions that are indicators of critical thinking skills. In addition, the use of multimedia provides visualization of concepts better way so that it can provide real concept learning experiences to students (Crozat et al., 1999).

Table 7. The comparison of multimedia revision

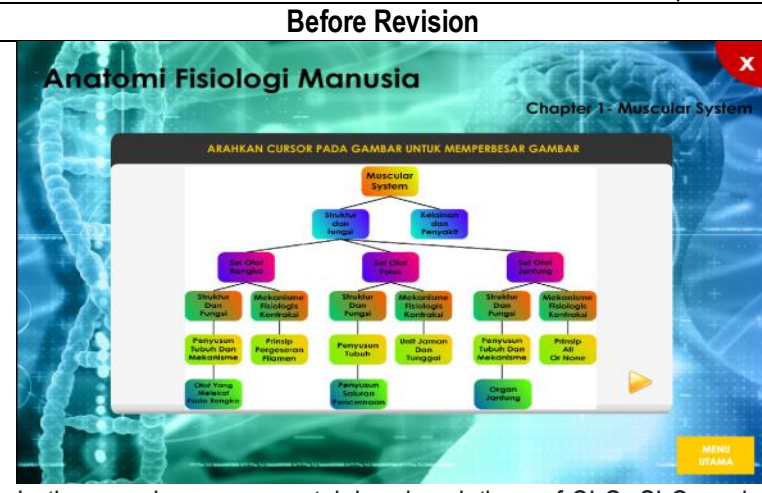

In the overview menu containing descriptions of CLO, SLO, and concept maps, there were not any navigation button to the materials' menu, so users still have to go to the main menu.

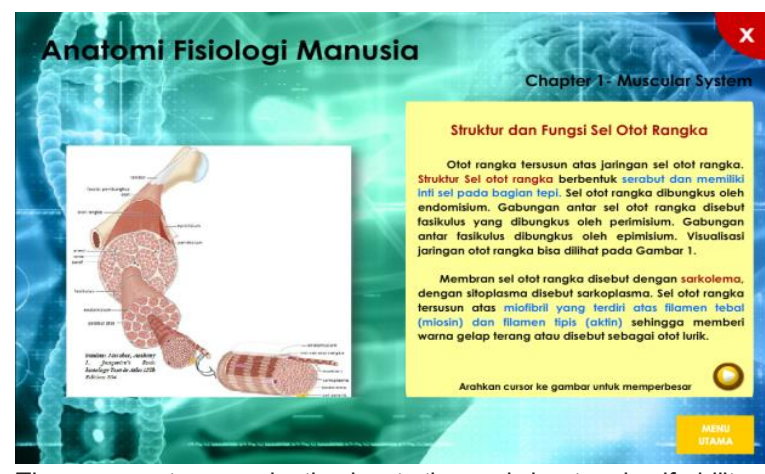

There was not any navigation key to the worksheet and self-ability so it was less efficient if the users should go first to the main menu.

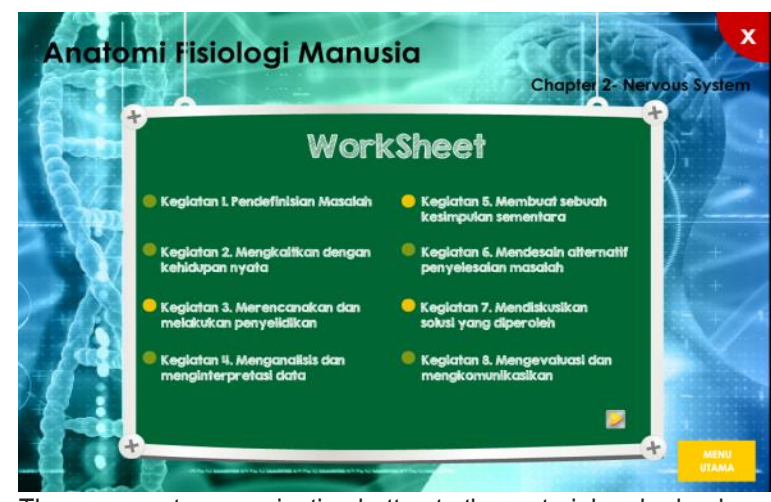

There was not any navigation button to the material and e-books, so that the students were difficult to access the material.

\section{After Revision}

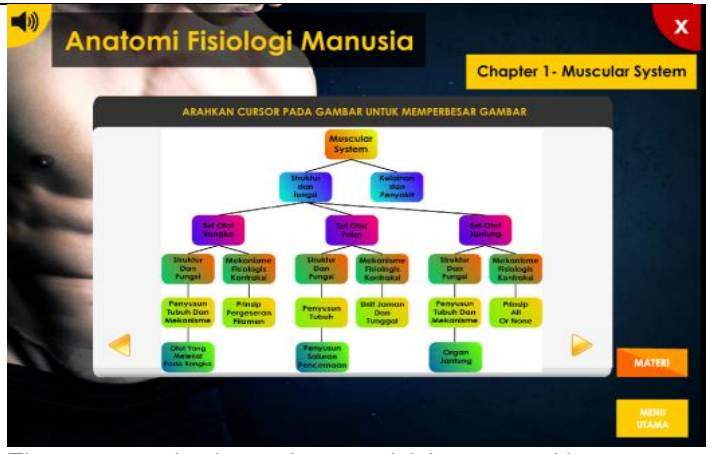

There was navigation to the materials' menu, making users were easier and faster access to switch to the materials' menu.

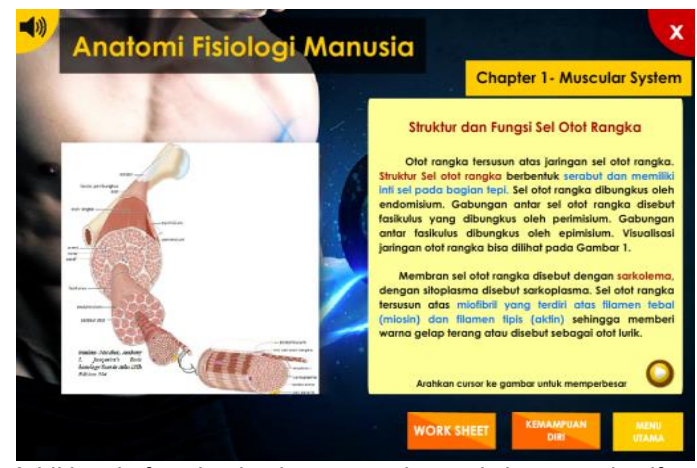

Additional of navigation buttons to the worksheets and selfabilities, in order to speed up access to other menus.

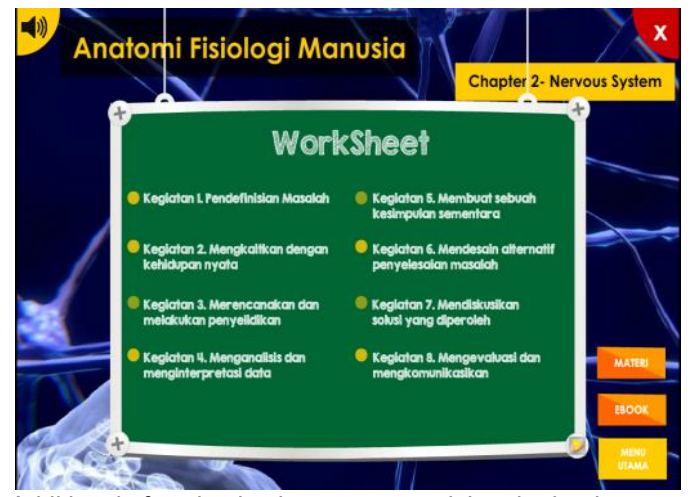

Additional of navigation button to material and e-book 


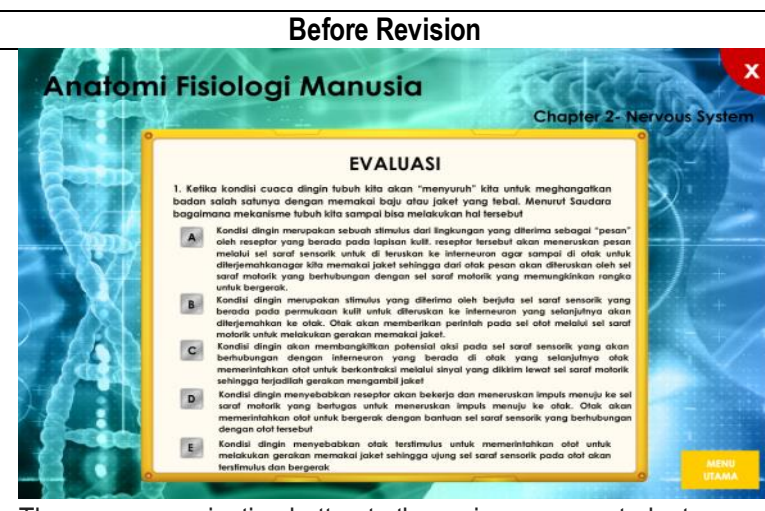

There was a navigation button to the main menu so students can access material allowing cheating by looking at the material.

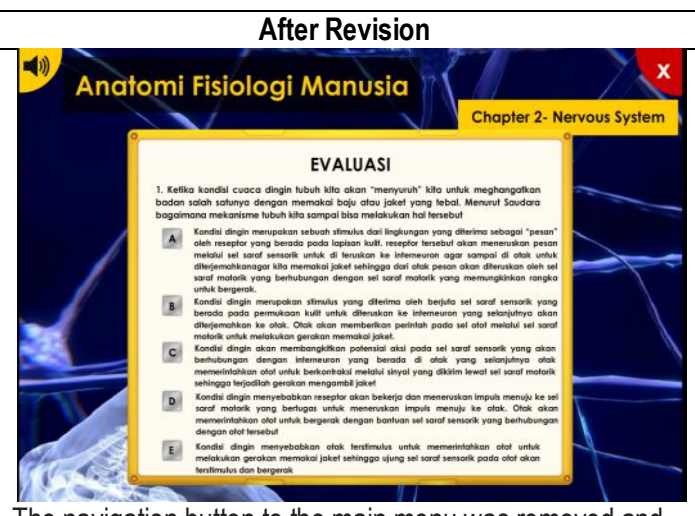

The navigation button to the main menu was removed and only appeared again when the students have completed the question and saw the score obtained.

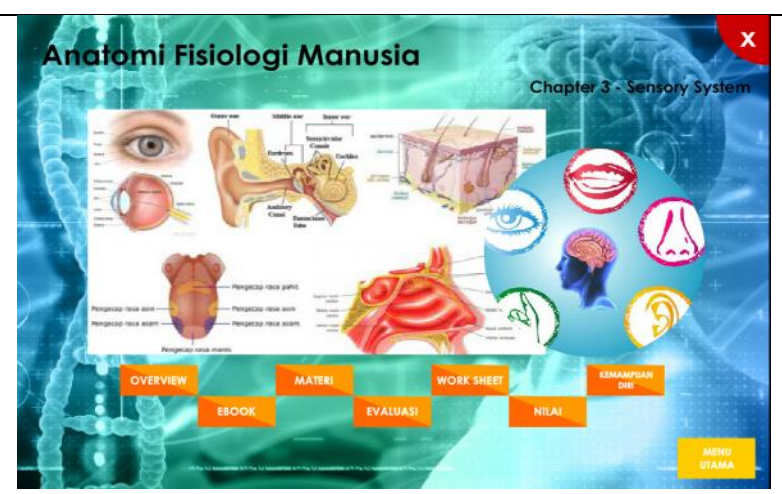

The use of background images that interfere the attractiveness and content were because they contained information and score menu still appeared, in which it should be integrated in the evaluation

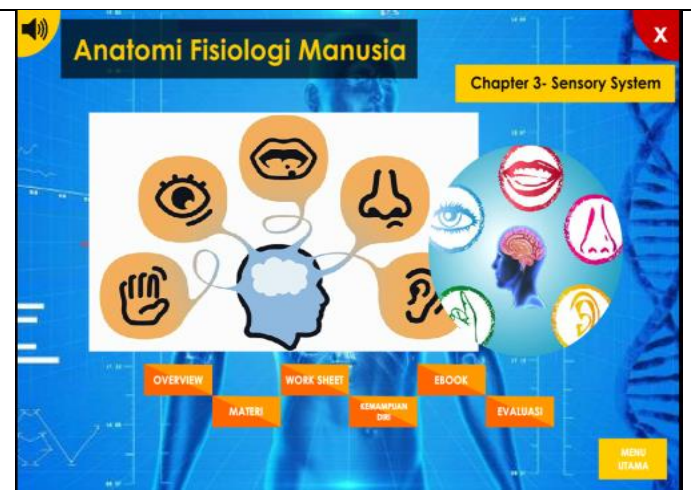

Replacement of mages illustration and deletion of score menu

Table 8. Multimedia trial results

\begin{tabular}{clcc}
\hline No & \multicolumn{1}{c}{ Question } & Score (\%) & Criteria \\
\hline 1 & Identity of multimedia is clear & 84.87 & Very valid \\
2 & Images in the multimedia can help to understand concepts. & 88.16 & Very valid \\
3 & The language used in the multimedia is clear & 86.84 & Very valid \\
4 & Menu in the multimedia can help you to use it & 75.00 & Valid \\
5 & Instruction of evaluation worksheet in multimedia is easy to be understood. & 85.53 & Very valid \\
6 & The language used in the matter of evaluation in multimedia is easy to be understood. & 85.53 & Very valid \\
7 & This multimedia can trigger your motivation. & 91.45 & Very valid \\
8 & This multimedia can lead you to the independence learning. & 80.92 & Valid \\
9 & The multimedia can improve your critical thinking skill. & 92.11 & Very valid \\
10 & Material in the multimedia is relevant to support you learning human physiology anatomy & 87.50 & Very valid \\
11 & Material in the multimedia is structured systematically and easily understood. & 84.87 & Very valid \\
12 & Learning with the multimedia can increase learning motivation. & 75.00 & Valid \\
13 & Learning with the multimedia make you easier to learn human physiology anatomy & 86.84 & Very valid \\
& material. & 82.89 & Very valid \\
14 & Questions' type in the multimedia can foster your critical thinking & 88.16 & Very valid \\
15 & Students' activities contained in the worksheet and self-ability is appropriate with the flow & & \\
& of STEM education learning model & 87.50 & Very valid \\
16 & The evaluation menu can measure your understanding level of concepts being studied. & & Very valid \\
17 & The multimedia which is supported by images, text, and videos, helps you to understand & 85.53 & \\
\hline & the concept & & \\
\hline
\end{tabular}

Table 9. Prerequisite test results

\begin{tabular}{cc}
\hline Type of testing & Result \\
\hline One-sample Kolmogorov-Smirnov & 0.821 \\
Levene's Test & 0.610 \\
\hline
\end{tabular}


Table 10. ANACOVA test results

\begin{tabular}{lccccc}
\hline \multicolumn{1}{c}{ Source } & $\begin{array}{c}\text { Type III sum of } \\
\text { squares }\end{array}$ & df & Mean square & F & Sig. \\
\hline Corrected Model & $8774.657 a$ & 2 & 4387.328 & 16.234 & .000 \\
Intercept & 29477.712 & 1 & 29477.712 & 109.074 & .000 \\
Pretest & 1958.867 & 1 & 1958.867 & 7.248 & .009 \\
Class & 4697.837 & 1 & 4697.837 & 17.383 & .000 \\
Error & 19728.530 & 73 & 270.254 & & \\
Total & 299857.812 & 76 & & & \\
Corrected Total & 28503.187 & 75 & & &
\end{tabular}

On other hand, Baharin et al (2018) stated that STEM education can improve students' high-level thinking skills, especially critical thinking skills because the STEM model can direct students to solve problems, think critically, think creatively, and think scientifically. STEM-based multimedia produced in this study can be used as a basis for further innovative development. Some research that has been done related to STEM-based teaching materials is still limited to print media (Baram-Tsabari \& Lewenstein, 2013; Lestari, Astuti, \& Darsono, 2018). In addition, the results of this study can also be used as further study material in presenting other biological material with more complex characteristics.

\section{CONCLUSION}

Multimedia anatomy of human physiology based on STEM education that has been developed is declared valid in the aspects of media feasibility $(96.89 \%)$, material $(89.31 \%)$, usefulness $(97.53 \%)$, and readability $(85.22 \%)$. Furthermore, multimedia is effective in empowering students' critical thinking skills. The results of this study recommend further development in order to effectively increase student motivation and learning independence.

\section{ACKNOWLEDGMENT}

This research was funded through the DRPM (Direktorat Riset dan Pengabdian Masyarakat or Directorate of Research and Community Engagement of Ministry of Research and Technology of the Republic of Indonesia) funding scheme in collaboration with IKIP Budi Utomo Malang, East Java-Indonesia. Highest appreciation to all components involved in this research such as practitioners, media development experts, and students.

\section{REFERENCES}

Aflalo, E., \& Gabay, E. (2013). Learning approach and learning: Exploring a new technological learning system. International Journal for the Scholarship of Teaching and Learning, 7(1), 1-19. doi: https://doi.org/10.204 29/ijsotl.2013.070114

Akopian, D., Melkonyan, A., Golgani, S. C., Yuen, T. T., \& Saygin, C. (2013). A template-based short course concept on android application development. Journal of Information Technology Education: Innovations in Practice, 12, 13-28. Retrieved from https://nsf.gov/awardsearch/showAward?AWD_ID=0942852

Ary, D., Jacobs, L. C., Sorensen, C., \& Razavieh, A. (2010). Introduction to research in education (Eighth). Belmont, CA: Wadsworth Cengage Learning. Retrieved from http://www.modares.ac.ir/uploads/Agr.Oth. Lib.12.pdf

Ashaver, D., \& Igyuve, S. M. (2013). The use of audio-visual materials in the teaching and learning processes in colleges of education in Benue State-Nigeria. IOSR Journal of Research \& Method in Education (IOSRJRME), 1(6), 44-55. doi: https://doi.org/10.9790/7388-0164455

Azizah, Z. F., Kusumaningtyas, A. A., Anugraheni, A. D., \& Sari, D. P. (2018). Validasi preliminary product FungCube pada pembelajaran fungi untuk siswa SMA. Jurnal Bioedukatika, 6(1), 15. doi: https://doi.org/10.265 55/bioedukatika.v6i1.7364

Bahar, M., Aydin, F., \& Karakirik, E. (2009). A diagnostic study of computer application of structural 
communication grid. The Turkish Online Journal of Educational Technology - TOJET, 8(2), 5-19. Retrieved from http://www.tojet.net/articles/v8i2/821.pdf

Baharin, N., Kamarudin, N., \& Manaf, U. K. A. (2018). Integrating STEM education approach in enhancing higher order thinking skills. International Journal of Academic Research in Business and Social Sciences, 8(7), 810-821. doi: https://doi.org/10.6007/ijarbss/v8-i7/4421

Bahri, S., Syamsuri, I., \& Mahanal, S. (2016). Pengembangan modul keanekaragaman hayati dan virus berbasis model inkuiri terbimbing untuk siswa kelas X MAN 1 Malang. Jurnal Pendidikan: Teori, Penelitian, Dan Pengembangan, 1(2), 127-136. doi: https://doi.org/10.17977/jp.v1i2.6113

Baram-Tsabari, A., \& Lewenstein, B. V. (2013). An instrument for assessing scientists' written skills in public communication of science. Science Communication, 35(1), 56-85. doi: https://doi.org/10.1177/10755470 12440634

Bellanca, J., Brandt, R., Barell, J., Darling-Hammond, L., Dede, C., Dufour, R., ... Seif, E. (2010). 21st century skills: Rethinking how students learn. In J. Bellanca \& R. Brandt (Eds.), 21st century skills: Rethinking how students learn (pp. 1-27). Solution Tree Press. Retrieved from http://www.edugains.ca/resources 21CL/Research/Readings/21stCenturySkills_Re-ThinkingHowStudentsLearn.pdf

Binkley, M., Erstad, O., Herman, J., Raizen, S., Ripley, M., Miller-Ricci, M., \& Rumble, M. (2012). Defining twenty-first century skills. In P. Griffin, B. McGaw, \& E. Care (Eds.), Assessment and teaching of 21st century skills (pp. 17-66). Dordrecht: Springer. doi: https://doi.org/10.1007/978-94-007-2324-5

Chu, S. K. W., Reynolds, R. B., Tavares, N. J., Notari, M., \& Lee, C. W. Y. (2016). 21st century skills development through inquiry-based learning: From theory to practice. 21st Century Skills Development Through Inquiry-Based Learning: From Theory to Practice. doi: https://doi.org/10.1007/978-981-10-24818

Çimer, A. (2012). What makes biology learning difficult and effective: Students' views. Educational Research and Reviews, 7(3), 61-71. doi: https://doi.org/10.5897/ERR11.205

Cronje, J. (2016). Learning technology in higher education. In The Wiley Handbook of Learning Technology (pp. 131-144). doi: https://doi.org/10.1002/9781118736494.ch8

Crozat, S., Hu, O., \& Trigano, P. (1999). A method for evaluating multimedia learning software. In International Conference on Multimedia Computing and Systems -Proceedings (Vol. June, pp. 714-719). IEEE. doi: https://doi.org/10.1109/MMCS.1999.779287

Dick, W., Carey, L., \& Carey, J. O. (2015). The systematic design of instruction (Sixth). Pearson. Retrieved from http://butleratutb.pbworks.com/w/file/fetch/54301965/table of contents preface intro.pdf

Dwyer, C. P., Hogan, M. J., \& Stewart, I. (2014). An integrated critical thinking framework for the 21st century. Thinking Skills and Creativity, 12, 43-52. doi: https://doi.org/10.1016/j.tsc.2013.12.004

Ertmer, P. A., \& Newby, T. J. (2013). Behaviorism, cognitivism, constructivism: Comparing critical features from an instructional design perspective. Performance Improvement Quarterly, 24(3), 55-76. doi: https://doi. org/10.1002/piq. 21143

Fitriani, U., Adisyahputra, A., \& Komala, R. (2018). Eco-friendly website development in biology learning based on project activities on environmental pollution. Biosfer, 11(1), 33-47. doi: https://doi.org/10.21009/biosfer jpb.11-1.4

Groshans, G., Mikhailova, E., Post, C., Schlautman, M., Carbajales-Dale, P., \& Payne, K. (2019). Digital story map learning for STEM disciplines. Education Sciences, 9(2), 1-17. doi: https://doi.org/10.3390/educsci9 020075

Guleker, R. (2015). Instructional strategies to foster critical thinking: Self-reported practices of the faculty in Albania. International Journal of Teaching and Education, III(4), 6-14. doi: https://doi.org/10.20472/TE. 2015.3.4.002

Hidayati, N. (2016). Pengembangan petunjuk instruksional kegiatan praktikum materi sistem gerak dan sistem koordinasi pada mata kuliah Anatomi Fisiologi Manusia. Paradigma: Jurnal Filsafat, Sains, Teknologi, Dan Sosial Budaya, 22(2), doi: 119-122. https://doi.org/10.33503/paradigma.v22i2.492

Himschoot, A. R. (2012). Student perception of relevance of biology content to everyday life: A study in higher education biology courses. ProQuest Dissertations and Theses. Capella University. Retrieved from https://digitalcommons.olivet.edu/biol_facp/2/

Huff, P. L. (2014). The goal project: A group assignment to encourage creative thinking, leadership abilities and communication skills. Accounting Education: An International Journal, 23(6), 582-594. doi: https://doi.org/ 10.1080/09639284.2014.974198 
Ichsan, I. Z., Sigit, D. V., Miarsyah, M., Ali, A., Arif, W. P., \& Prayitno, T. A. (2019). HOTS-AEP: Higher order thinking skills from elementary to master students in environmental learning. European Journal of Educational Research, 8(4), 935-942. doi: https://doi.org/10.12973/eu-jer.8.4.935

Iriti, J., Bickel, W., Schunn, C., \& Stein, M. K. (2016). Maximizing research and development resources: identifying and testing "load-bearing conditions" for educational technology innovations. Educational Technology Research and Development, 64(2), 245-262. doi: https://doi.org/10.1007/s11423-015-94092

Irwan, I., Maridi, M., \& Dwiastuti, S. (2019). Developing guided inquiry-based ecosystem module to improve students' critical thinking skills. JPBI (Jurnal Pendidikan Biologi Indonesia), 5(1), 51-60. doi: https://doi.o rg/10.22219/jpbi.v5i1.7287

Isaacs, S. (2012). Turning on mobile learning in Africa and the Middle East. UNESCO Working Paper Series on Mobile Learning. Paris. doi: https://doi.org/216358

Ismail, N. S., Harun, J., Zakaria, M. A. Z. M., \& Salleh, S. M. (2017). The effect of mobile problem-based science dictionary application dicscience PBL towards students' mastery of scientific terms and critical thinking. In 2017 International Conference on Learning and Teaching in Computing and Engineering (LaTICE) (pp. 69-75). IEEE. doi: https://doi.org/10.1109/LaTiCE.2017.19

Iversen, A., Pedersen, A. S., Krogh, L., \& Jensen, A. A. (2015). Learning, leading, and letting go of control: Learner-led approaches in education. SAGE Open, 5(4), 1-11. doi: https://doi.org/10.1177/21582440156 08423

Jack, G. U. (2013). The influence of identified student and school variables on students' science process skills acquisition. Journal of Education Practice, 4(5), 16-23. Retrieved from https://www.iiste.org/Journals/ index.php/JEP/article/view/4783/4862

Kiliç, D., \& Sağlam, N. (2014). Students understanding of genetics concepts: The effect of reasoning ability and learning approaches. Journal of Biological Education, 48(2), 63-70. doi: https://doi.org/10.1080/00219266 .2013.837402

Korres, K., \& Tsami, E. (2013). Supporting the development of critical thinking skills in secondary education through the use of interdisciplinary statistics ' and mathematics ' problems. Journal of Interdisciplinary Mathematics, 13(5), 491-507. doi: https://doi.org/10.1080/09720502.2010.10700716

Leow, F.-T., \& Neo, M. (2014). Interactive multimedia learning: innovating classroom education in a Malaysian University. TOJET: The Turkish Online Journal of Educational Technology, 13(2), 99-110. Retrieved from http://www.tojet.net/articles/v13i2/13211.pdf

Lestari, D. A. B., Astuti, B., \& Darsono, T. (2018). Implementasi LKS dengan pendekatan STEM (science, technology, engineering, and mathematics) untuk meningkatkan kemampuan berpikir kritis siswa. Jurnal Pendidikan Fisika Dan Teknologi, 4(2), 202. doi: https://doi.org/10.29303/jpft.v4i2.809

Mader, S. S., \& Windelspecht, M. (2010). Human biology (12nd ed.). New York: McGraw-Hill. Retrieved from https://epdf.pub/human-biology-11th-edition6786ec7ea69836f42fb28f57e523091873696.html

Maria, U., Rusilowati, A., \& Hardyanto, W. (2019). Interactive multimedia development in the learning process of Indonesian culture introduction theme for 5-6 year old children. Journal of Primary Education, 8(3), 344-353. doi: https://doi.org/10.15294/jpe.v8i3.27029

McCrum, D. P. (2017). Evaluation of creative problem-solving abilities in undergraduate structural engineers through interdisciplinary problem-based learning. European Journal of Engineering Education, 42(6), 684-700. doi: https://doi.org/10.1080/03043797.2016.1216089

Mehdipour, Y., \& Zerehkafi, H. (2013). Mobile learning for education: benefits and challenges. In International Journal of Computational Engineering Research (Vol. 3, pp. 93-100). New Delhi. Retrieved from http:/l www.ijceronline.com/papers/Vol3_issue6/part\%203/P03630930100.pdf

Miharja, F. J., Hindun, I., Fauzi, A., Education, B., Malang, U. M., \& Citation, S. (2019). Critical thinking, metacognitive skills, and cognitive learning outcomes: A correlation study in genetic. Biosfer: Jurnal Pendidikan Biologi, 12(2), 135-143. doi: https://doi.org/10.21009/biosferjpb.v12n2.135-143

Muchlis, L. S., \& Putra, F. K. (2017). Development of mobile learning based-interactive multimedia in programming language class at STAIN Batusangkar. Jurnal Ta'Dib, 20(1), 72-84. doi: https://doi.org/10.3 1958/jt.v20i1.673

Nithyanantham, V., Paulmony, R., \& Hasan, S. R. (2019). Self-perspective of 21st Century educators: A challenge in the globalised educational world. International Journal of Educational Research Review, 4(3), 325-333. doi: https://doi.org/10.24331/ijere.573869 
Nurrohmah, F., Putra, F. G., \& Farida, F. (2018). Development of sparkol video scribe assisted learning media. Formatif: Jurnal IImiah Pendidikan MIPA, 8(3), 233-250. doi: https://doi.org/10.30998/formatif.v8i3.2613

Nusir, S., Alsmadi, I., Al-Kabi, M., \& Sharadgah, F. (2013). Studying the impact of using multimedia interactive programs on children's ability to learn basic math skills. E-Learning and Digital Media, 10(3), 305-319. doi: https://doi.org/10.2304/elea.2013.10.3.305

Oakes, D. J., Hegedus, E. M., Ollerenshaw, S. L., Drury, H., \& Ritchie, H. E. (2019). Using the jigsaw method to teach abdominal anatomy. Anatomical Sciences Education, 12(3), 272-283. doi: https://doi.org/10.10 02/ase.1802

Pang, C., Lau, J., Seah, C. P., Cheong, L., \& Low, A. (2018). Socially challenged collaborative learning of secondary school students in Singapore. Education Sciences, 8(24), 1-10. doi: https://doi.org/10.3390/ educsci8010024

Raaijmakers, S. F., Baars, M., Schaap, L., Paas, F., van Merriënboer, J., \& van Gog, T. (2018). Training selfregulated learning skills with video modeling examples: do task-selection skills transfer? Instructional Science, 46(2), 273-290. doi: https://doi.org/10.1007/s11251-017-9434-0

Rosli, M. S., Saleh, N. S., Aris, B., Ahmad, M. H., Sejzi, A. A., \& Shamsudin, N. A. (2015). E-learning and social media motivation factor model. International Education Studies, 9(1), 20. doi: https://doi.org/10.5539/ ies.v9n1p20

Rufii, R. (2015). Developing module on constructivist learning strategies to promote students' independence and performance. International Journal of Education, 7(1), 18-28. https://doi.org/10.5296/ije.v7i1.6675

Scott, C. L. (2015). The futures of learning 2: What kind of learning for the 21st Century? Retrieved from http://unesdoc.unesco.org/images/0024/002429/242996E.pdf

Siagian, S., Mursid, M., \& Wau, Y. (2014). Development of interactive multimedia learning in learning instructional design. Journal of Education and Practice, 5(32), 44-51. Retrieved from https://www.iiste. org/Journals/index.php/JEP/article/view/16711/17075

Song, D., \& Bonk, C. J. (2016). Motivational factors in self-directed informal learning from online learning resources. Cogent Education, 3(1), 1-11. doi: https://doi.org/10.1080/2331186X.2016.1205838

Suwono, H. (2016). School literary movement in Indonesia: Challenges for scientific literacy. Paper Presented at International Conference on Education, 309-317. Retrieved from http://pasca.um.ac.id/conferences/ index.php/ice/article/view/44

Talat, A., \& Chaudhry, H. F. (2014). The effect of PBL and 21st century skills on students' creativity and competitiveness in private schools. The Lahore Journal of Business, 2(2), 89-114. Retrieved from http://www.lahoreschoolofeconomics.edu.pk/businessjournals/V2issue2/05 Talat and Chaudhry FINAL .pdf

Thiagarajan, S., Semmel, D. S., \& Semmel, M. I. (1974). Instructional development for training teachers of exceptional children: A sourcebook. Council for Exceptional. Children, 1920 Association Drive, Reston, Virginia 22091. Retrieved from https://files.eric.ed.gov/fulltext/ED090725.pdf

Thompson, C. (2011). Critical thinking across the curriculum: Process over output. International Journal of Humanities and Social Science, 1(9), 1-7. Retrieved from http://www.ijhssnet.com/journals/Vol._1_No. _9_Special_Issue_July_2011/1.pdf

Torlakson, T. (2014). Innovate: A blueprint for science, technology, engineering, and mathematics in California Public Education. Californians Dedicated to Education Foundation. Californians Dedicated to Education Foundation All. Retrieved from https://www.cde.ca.gov/pd/ca/sc/documents/innovate.pdf

Tsuneyoshi, R. (2016). Models of schooling in the global age: the case of Japan. Revue Internationale D'education de Sevres, (September), 1-5. Retrieved from http://ries.revues.org/3899

Umachandran, K., Corte, V. Della, Amuthalakshmi, P., Ferdinand-James, D., Said, M. T., Sawicka, B., ... Jurcic, I. (2019). Designing learning-skills towards industry 4.0. World Journal on Educational Technology, 11(2), 12-23. Retrieved from https://www.researchgate.net/publication/332978312_Designing_learning-skills towards_industry_40

Valerio, K. M. (2012). Intrinsic motivation in the classroom. Journal of Student Engagement: Education Matters, 2(1), 30-35. Retrieved from https://ro.uow.edu.au/jseem/vol2/iss1/6/

Vieira, R. D., Melo, V. F. de, Avraamidou, L., \& Lobato, J. A. (2017). Reconceptualizing scientific literacy: The role of students' epistemological profiles. Education Sciences, 7(4), 47. doi: https://doi.org/10.3390/educ sci7020047 
Wang, Y., Wu, M., \& Wang, H. (2009). Investigating the deteminants and age and gender differences in the acceptance of mobile learning. British Journal of Educational Technology, 40(1), 92-118. doi: https://doi org/10.1111/j.1467-8535.2007.00809.x

West, D. M. (2015). Connected learning: How mobile technology can imporve education. Center for Technology Innovation at Brookings, (December), 1-8. Retrieved from https://www.brookings.edu/wp-content/upload s/2016/07/west_connected-learning_v11.pdf

Yusuf, M. M., Amin, M., \& Nugrahaningsih, N. (2017). Developing of instructional media-based animation video on enzyme and metabolism material. Jurnal Pendidikan Biologi Indonesia, 3(3), 254-257. doi: https://doi. org/10.22219/jpbi. v3i3.4744 